\author{
ks. Mateusz Ziemlewski \\ Uniwersytet Papieski Jana Pawta II w Krakowie \\ https://orcid.org/0000-0001-7822-3624 \\ mateusz.ziemlewski@gmail.com
}

\title{
Serce Jezusa jako istota chrystocentrycznej estetyki Josepha kard. Ratzingera/Benedykta XVI. Studium teologiczno-muzyczne na przyktadzie twórczości Henryka Mikołaja Cióreckiego
}

Wielu ludzi interesujących się zagadnieniami muzyki sakralnej wie, że tematyka sztuki, także muzycznej, znajdowała się w kręgu zainteresowań Josepha kard. Ratzingera. Jednakże warto zwrócić uwagę na rys teologiczny, z jakim kardynał interpretował estetykę. Wydaje się to konieczne zwłaszcza dziś, kiedy nie brakuje rozmaitych prób definicji dziedziny, jaką jest estetyka, a w nurcie awangardy także antyestetyka. Poniższy artykuł ma na celu wskazanie chrystologicznych podstaw estetyki muzyki w myśli kard. Ratzingera i stopnia, w jakim zostały one ufundowane na prawdzie wiary dotyczącej Najświętszego Serca Pana Jezusa. Z kolei muzyczne przykłady zaczerpnięte z twórczości Henryka Mikołaja Góreckiego mają stanowić nie tylko inkrustację teologicznego namysłu. Mają również wskazać na religijną wrażliwość kompozytora osnutą wokół postaci Jezusa Chrystusa. Wspomniany fakt często umyka uwadze. Prawdopodobnie wpływa na to popularny klucz interpretacyjny, podyktowany wczesną śmiercią matki kompozytora i wiązania twórczości religijnej z postacią Maryi oraz ewentualnie św. Jana Pawła II (okoliczności powstania, dedykacji i prawykonania utworu Beatus vir). Stąd teologia estetyki w wydaniu kard. Ratzingera ma stanowić pomoc w teologicznej interpretacji muzyki religijnej Henryka Mikołaja Góreckiego.

Kardynał poruszał temat muzyki w kontekście kościelnego kultu liturgicznego, pisał:

(...) pamiętajmy o jednym: od samego początku kult chrześcijański był kultem Bożym, różniącym się od życia codziennego. Od początku też 
charakteryzowało go to, że troszczono się o nową formę poetyckiego i muzycznego wyrazu chwalenia Boga i czyniono to z racji teologicznych ${ }^{1}$.

A zatem po pierwsze kult liturgiczny był odseparowany od życia powszedniego, co oznaczało społeczny podział na sacrum i profanum. Ta dychotomia dotyczyła nie tylko przestrzeni czy czasu, lecz także sztuki - od retoryki przez obraz do muzyki. Po drugie fundamentem dla sztuki sakralnej związanej ze świątynią są racje teologiczne. Dodać warto, że ten wniosek jest istotny dla dzisiejszej praktyki muzyki sakralnej. Szczególnie dotyczy koncertów w kościołach, w których na skutek błędnie rozumianej estetyki, wykonuje się utwory niesakralne. Innymi słowy, nie zawsze racje teologiczne znajdują swoje miejsce w organizacji sakralnego życia muzycznego. Tymczasem linia teologicznego dowodzenia kardynała jest jednoznaczna: Bóg - teologia - kult - sztuka sakralna (muzyka sakralna).

Kardynał Ratzinger opierał chrystologię na trzech dogmatach - stworzenia, wcielenia i odkupienia. Te aksjomaty pozwalają na teologiczną orientację w estetyce. Istotą kultu jest zdaniem teologa Logos, czyli sens wszystkich rzeczy. Logos łączy się z dogmatem stworzenia. Chrześcijaństwo przejęło wcześniej istniejący schemat dotyczący powstania świata: exitus i redditus. Exitus to ontyczny fakt stworzonej rzeczywistości, która może trwać naprzeciw (obok) Stwórcy. W przeciwieństwie do mitologii, exitus w teologii nie jest czymś negatywnym. Bóg stwarza życie, a człowiek tęskniąc za Bogiem, może do Niego powrócić - redditus ${ }^{2}$. Wymiarem ludzkiego redditus jest kult, czyli wolna odpowiedź na miłość Boga ${ }^{3}$. W tej perspektywie grzech pierworodny, a w następstwie każdy grzech jest wolnym sprzeciwem wobec boskiej miłości. Ta ostatnia uważana jest wówczas za zależność i skrępowanie stworzenia. Nie wchodząc w szczegóły, trzeba tu zauważyć pewien rekurs do współczesności, pisał Ratzinger:

(...) dzisiaj przeżywamy nie tylko kryzys sztuki sakralnej, lecz także kryzys sztuki w ogóle, i to w stopniu dotychczas nieznanym. Kryzys sztuki jest z kolei symptomem kryzysu człowieczeństwa. Ludzkość bowiem wraz z niezwykłym wzrostem materialnego panowania nad światem uległa jednocześnie w sprawach wykraczających ponad poziom materii i dotyczących

1 J. Ratzinger, Teologia liturgii, tłum. W. Szymona OP, Lublin 2012, s. 541 (Opera Omnia, 11).

2 Zob. J. Ratzinger, Teologia liturgii, s. 40-41.

3 Zob. J. Ratzinger, Zmartwychwstanie i życie wieczne, tłum. J. Kobienia, Lublin 2014, s. 576 (Opera Omnia, 10). 
zasadniczej orientacji człowieka takiemu zaślepieniu, że można je nazwać po prostu duchową ślepotą .

Słowem, kult Boga został zastąpiony kultem człowieka, który „może wszystko”. Kultem nie jest już powrót do Stwórcy, ale uwielbienie dla stworzenia. Cenną uwagę wniósł w tym względzie antropolog Arnold Gahlen, badający problem człowieka w stechnicyzowanym świecie. Otóż filozof zarysował dwie pary skrajnych postaw ludzkich: człowiek kulturalny - człowiek masowy oraz osobowość i indywidualność. Człowiek kulturalny i osobowość to ktoś, kto nie poddaje się swoim emocjom ani racjonalizmowi, nie polega na opiniach z drugiej ręki; przeciwnie do człowieka masowego, który niezdolny do ascezy, nastawia się jedynie na przyjemnościową konsumpcję. Podczas gdy osobowość nie pragnie się specjalnie wyróżniać, poddaje się ascezie i dąży do obiektywnych celów, to indywidualność koncentruje się na sobie z ekscentrycznie rozbujałą subiektywnością i wrażliwością nad własną odmiennością. Indywidualność to nieprzypadkowy epitet (o pozytywnej konotacji) dla wielu artystów, którzy w swoim emploi obracają się jedynie wokół samych siebie. We własnych wytworach sztuki niczego nie naśladują, tylko wyrażają siebie i swoją indywidualną odmiennośćs. A zatem, wracając do myśli Ratzingera, duchowa ślepota stanowi wyraz błędnej antropologii i leży u podstaw człowieka masowego (nie kulturowego) oraz indywidualności. Intuicja Arnolda Gahlena, dotycząca człowieka kulturalnego, pozwala uchwycić sens słowa kultura i kult, z jego wspólnym dla obydwu wyrazów łacińskim rdzeniu: colo, colui, cultum 'pielęgnować, mieć staranie, uszlachetniony, wykwintny, czcić, uważać za święte'6.

Człowiek kultury to człowiek kultu do Kogoś lub czegoś poza sobą samym. W przeciwnym razie rodzi się antykultura ślepa na sens rzeczywiści - Logos.

Warto przyjrzeć się czy i w jaki sposób kult religijny znajdował swoje miejsce w twórczości Henryka Mikołaja Góreckiego. A zważywszy na poruszany temat, należy uszczegółowić pytanie: czy kult Najświętszego Serca Pana Jezusa miał swoje reminiscencje w twórczości kompozytora? Szczególnym wyrazem tego kultu w Kościele katolickim jest litania, która powstała z wezwań zapisanych w czasie epidemii cholery, panującej w Marsylii w latach 1720-1722. Ponadto kilka wezwań pochodzi z roku 1686 (przypuszcza się, że część jest autorstwa św. Małgorzaty Marii Alacoque) oraz 1691. Litanię zatwierdził papież Leon XIII 2 kwietnia 1839

4 J. Ratzinger, Zmartwychwstanie i życie wieczne, s. 108.

5 Zob. E. Paczkowska-Łagowska, O historyczności cztowieka, Gdańsk 2012, s. 166-167.

6 Zob. Stownik tacińsko-polski, red. K. Kumaniecki, Warszawa 1982, s. 97. 
$\mathrm{roku}^{7}$. I co ważne, motyw melodii wileńskiej towarzyszący litanijnym wezwaniom: „Serce Jezusa”, możemy spotkać w jednym z utworów Góreckiego. Warto najpierw zaznaczyć, że kompozytor odnosił się z wielką pieczołowitością do warstwy słownej swoich utworów. Bardzo cenił twórczość poetycką, a sam cytując jakieś słowa, zgłębiał ich treść i źródła naukowe tekstu ${ }^{8}$. W tym sensie w dziele Salve sidus Polonorum. Kantata ośw. Wojciechu op. 72 pojawił się cymes w postaci tekstu autorstwa samego kompozytora: „Święty Wojciechu/ Patronie nasz drogi/ Męczenniku Boży/ módl się za nami/ Sancte Adalberte/ Patrone noster/ Martyt Dei/ ALLELUJA" I właśnie te słowa Górecki opatrzył (w partii sopranów i altów) incipitem melodii zaczerpniętej z wileńskiej melodii Litanii do Najświętszego Serca Pana Jezusa ${ }^{10}$ [zob. 1. Przykład nutowy na końcu artykułu]. Znając pieczołowitość i drobiazgowość osoby kompozytora taki dobór nie był czymś przypadkowym. Zwłaszcza że cały utwór został gatunkowo zaszeregowany przez niego jako kantata. Podczas gdy drugą część oparł na muzyce z Litanii do Serca Pana Jezusa, to finałową część trzecią, ufundował na melodii pochodzącej z hymnu liturgicznego Lauda Sion Salvateorem. Hymn posłużył Jakubowi Śwince do napisania tekstu dedykowanego św. Wojciechowi ${ }^{11}$, którego tytuł i melodię zapożyczył Górecki. W bogactwie słownych i muzycznych inspiracji pojawienie się melodii z Litanii do Serca Pana Jezusa nie jest przypadkowe, zwłaszcza że swoim wyrazem nadaje dziełu kultyczno-religijny wyraz muzyczny, nacechowany stylistką liturgiczną.

Wracając do kard. Ratzingera, należy zauważyć, że porównał on Słowo Przedwieczne do obrazu Pasterza, który w akcie redditus bierze ludzkość na swoje ramiona i przynosi do Ojca:

Logos, Słowo Przedwieczne, odwieczny, istniejący w Synu Bożym sens wszystkich rzeczy, który sam wyrusza w drogę do nas i bierze owcę na ramiona, to znaczy przyjmuje ludzką naturę i jako Bóg-Człowiek stworzonego człowieka przynosi z powrotem do domu ${ }^{12}$.

Przyjęcie ludzkiej natury oznacza asymilację przez Boga ludzkiego ciała. Wcielenie Logosu to spełnienie narracji Biblii, która rozpoczyna się od pierwszych

7 Por. S. Szymański, Litania do Najświętszego Serca Jezusowego, „Ateneum Kapłańskie” 62 (1961) z. 3, s. 263-264.

8 Zob. W. Siedlik, Henryk Mikotaj Górecki i jego muzyka, „Pro Musica Sacra” 10 (2012), s. 91, 101.

9 H.M. Górecki, Salve, sidus Polonorum op. 72, London, s. 5.

10 Zob. J. Siedlecki, Śpiewnik kościelny, Kraków 2007, s. 739.

11 Zob. J. Pikulik, Święty Wojciech w polskiej muzyce średniowiecznej, Warszawa 1996, s. 190.

12 J. Ratzinger, Teologia liturgii, s. 41. 
słów Starego Testamentu, od stworzenia świata poprzez dzieje Kościoła. Narracja i prolog do Ewangelii wg św. Jana, ukazują wieczne pochodzenie Chrystusa, dla którego ziemskie ciało stanowi jakby namiot Słowa. Życie Jezusa Chrystusa nie nastąpiło w mitologicznych zaświatach, ale w konkretnym czasie i miejscu, co oznacza realną rzeczywistość ziemską. Logos - odwieczny sens stał się człowiekiem $^{13}$. Nieprzypadkowym symbolem jest zatem serce, oznaczające organ woli, który stanowi adekwatną miarę człowieczeństwa. Mówiąc najkrócej i najprościej jak się da - Serce Pana Jezusa ucieleśnia dobrą wolę Boga wobec rodzaju ludzkiego oraz poszczególnego człowieka. Kardynał wskazał na starotestamentalne opowiadanie o potopie, które unaocznia spotkanie woli człowieka i Boga. Potop nastąpił na skutek ludzkich grzechów, czyli złej ludzkiej woli. Z kolei: „wejrzenie serca Bożego na słabość człowieka spowoduje, że w przyszłości nigdy już nie wyda takiego wyroku" ${ }^{14}$. W innym z tekstów teolog tłumaczył dokładniej, na czym polega spotkanie ludzkiej i boskiej woli w Sercu Pana Jezusa. Istota rozumowania opiera się na dogmacie chalcedońskim. Chrystus miał „wolę osobową”, która włączała w boską wolę „wolę naturalną” (ludzka). Wola ludzka zawierała człowieczy opór powrotu do Boga, który w Sercu Chrystusa został przezwyciężony. Dokonało się w Nim centrum kultu - człowiek wrócił do Boga ${ }^{15}$. Należy zaznaczyć, że w tym miejscu ukazała się teologiczna istota kultu i kultury, jakim jest pojednanie. Estetyka interpretowana teologicznie oznacza kategorię piękna, które pozwala jednać ludzi z Bogiem i między sobą. Dramat antyestetyki i antykultury, jako wykwitów „herezji marksistowskiej” ${ }^{16}$ polega na hodowaniu w człowieku buntu i złości, a nawet nienawiści do gatunku ludzkiego ${ }^{17}$. Pisała Anna Maria Potocka, broniąc słuszności demokratyzacji sztuki, a nie elitarności twórców i dzieł:

(...) nadprodukcja artystów wiąże się ze sporym dyskomfortem życiowym ludzi marzących o cudownym odkryciu i światowym sukcesie. Jednak dla kultury - która bardziej przypomina amoralny mechanizm ewolucyjny niż system etyczny - wypuszczenie setek osób na ambicjonalne męczarnie jest korzystne. Dzięki temu znacznie powiększyło się pole wyboru ${ }^{18}$.

13 J. Ratzinger, Jezus z Nazaretu, tłum. M. Górecka, W. Szymona OP, Lublin 2015, s. 44, 76 (Opera Omnia, 6/1).

14 J. Ratzinger, Jezus z Nazaretu, tłum. W. Szymona OP, Lublin 2015, s. 626 (Opera Omnia, $6 / 2)$.

15 J. Ratzinger, Jezus z Nazaretu, s. 493 (Opera Omnia, 6/1).

16 J. Ratzinger, Teologia liturgii, s. 199.

17 Zob. J. Ratzinger, Wprowadzenie do chrześcijaństwa, tłum. R. Biel, M. Górecka, Lublin 2017, s. 403, 729 (Opera Omnia, 4).

18 A.M. Potocka, Nowa estetyka, Warszawa 2016, s. 28. 
Żeby przekonać się o poziomie zdemokratyzowanej sztuki, wystarczy posłuchać kilku youtuberów. Przywołując antropologiczną intuicję Gahlena, można powiedzieć o ambicjonalnych męczarniach indywidualistów. Nie należy się okłamywać, że taka postawa nie pojawia się także w „nowej estetyce katolickiej”. A co stanowi o takowej? Zapomnienie teologicznych podstaw dla sztuki sakralnej i estetyki wiary. Warto jeszcze wspomnieć, że przed takimi ambicjonerami w muzyce kościelnej przestrzegał kardynał, kiedy pisał: „pojawia się jednak niebezpieczeństwo wtargnięcia wirtuozerii, próżności w eksponowaniu własnych zdolności podmiotu, który nie chce już służyć dobru całości, lecz na pierwszy plan wysuwa siebie samego" ${ }^{19}$. Zwłaszcza doświadczenie organizowanych koncertów w kościołach ukazuje, że ta przestroga kardynała jest bardzo aktualna ${ }^{20}$. Zarówno repertuar, jak miejsce i sposób wykonania niejednokrotnie druzgoczą teologiczne znaczenie świątyni i prezbiterium, zrównując je z salą koncertową oraz estradą. To niechlubnie wpisuje się w działania antykultury, niemającej nic wspólnego z teologiczną estetyką muzyki. Wirtuozeria w przytoczonym fragmencie nie ma na celu ośmieszenia czy zdewaluowania warsztatu muzyka. Przeciwnie, kardynał twierdził, że muzyk musi być ekspertem ${ }^{21}$, ale tutaj oznacza chęć stanięcia w centrum uwagi. Przypominając intuicję Gahlena, wirtuoz ma być osobowością, a nie indywidualnością. Trzeba podkreślić, że miejsce święte to miejsce kultu, czyli uwielbienia Boga. Kiedy człowiek zaczyna zajmować miejsce Boga, to miejsce kultu staje się miejscem anty-kultu religijnego. A co za tym idzie, muzyka staje się narzędziem antykultury; pisał teolog:

(...) rozkład podmiotu - proces, który dzisiaj przeżywamy jednocześnie z radykalnymi formami subiektywizmu - doprowadził do dekonstruktywizmu, do anarchicznej teorii kultury ${ }^{22}$.

Tymczasem Serce Jezusa Chrystusa w kontekście spotkania i pojednania, tego co boskie i ludzkie, ukazuje istotny asumpt dla sztuki sakralnej oraz predyspozycji twórcy:

Wcielenie Boga było Jego wejściem w materię, zapoczątkowaniem wielkiego ruchu, w którym cała materia ma się otwierać na przyjęcie Słowa, podczas gdy również Słowo ma ze swej strony wyrażać się w materii, oddawać

19 J. Ratzinger, Teologia liturgii, s. 120.

20 Wystarczy wpisać w youtube hasło: koncert w kościele.

21 Zob. J. Ratzinger, Teologia liturgii, s. 563.

22 J. Ratzinger, Teologia liturgii, s. 126. 
się jej, ażeby móc ją przemieniać. Dlatego pojawia się teraz radość z tego, że wiara może się stawać widzialna i wznosić swoje znaki w świecie materii ${ }^{23}$.

Sakralna sztuka muzyczna to znaki w świecie materii, które prowadzą do Boga. Znaki mają być możliwie doskonałe, bowiem wyrażają doskonałość Boga. Tu znajduje się doniosła rola artysty. Teolog podkreślał, że u źródeł muzyki sakralnej znajdują się „szacunek, przyjęcie i pokora” ${ }^{24}$. Jedynie takie uposażenie antropologiczne pozwala na tworzenie muzyki rezonującej a nie profanującej sacrum. Teologiczna estetyka wiary wymaga od twórcy osobowości, a nie indywidualizmu. Przywołane przez kard. Ratzingera cechy, to w zasadzie echo słów Chrystusa, tej Osobowości, która jest fundamentem kultury chrześcijańskiej. A zważywszy na źródłosłów wyrazu „chrześcijaństwo”, należy w dobie kolejnych samozwańczych zbawców ludzkości (ambicjonalnych indywidualistów) rzec KULTURY CHRYSTUSOWEJ: "Weźcie moje jarzmo na siebie i uczcie się ode Mnie, bo jestem cichy i pokorny sercem, a znajdziecie ukojenie dla dusz waszych" (Mt 11, 29). Kultura chrześcijańska to próba wprowadzenia w życie społeczeństw różnych czasów i miejsc kultury samego Jezusa Chrystusa, mającej swoje źródło w Jego Najświętszym Sercu.

Chrystusowego ukojenia dla uciemiężonego narodu polskiego szukał Henryk Mikołaj Górecki w Biblii i Mszale rzymskim, kiedy komponował swoje dzieło Miserere. Stanowi ono wyraz katolickiej pobożności kompozytora. Asumptem do powstania utworu były wydarzenia z 1981 roku, które dokonały się w Bydgoszczy. Milicja Obywatelska zaatakowała strajkujących członków „Solidarności wiejskiej”. Górecki napisał muzykę zadedykowaną Bydgoszczy ${ }^{25}$. Jest to jedyny utwór, poprzez który muzyk zareagował na polityczno-społeczne wydarzenia. Czy możemy dostrzec w nim konotację z Sercem Jezusa? Należy zauważyć, że tekst słowny nie zawiera słów z manifestów politycznych, ale z Psalmu 106,47 oraz tytułowe Miserere z Mszału Rzymskiego (zapisane w partyturze wielkimi literami) ${ }^{26}$. To nie przypadek, że ostatnie słowo stało się tytułem. Utwór podzielony został na jedenaście części, w których kompozytor różnorodnie zaakompaniował słowa. Dziesięć części to muzyczna kontemplacja trzech słów: Domine Deus noster. Z kolei finałowa część stanowi muzyczną adaptację tekstu z mszalnej części Agnus Dei. Została ona wprowadzona do liturgii przez papieża Sergiusza I w VII wieku. W XI wieku trzecie wezwanie zamieniono z miserere nobis na dona nobis pacem. Śpiew wykonywany

23 J. Ratzinger, Teologia liturgii, s. 427.

24 J. Ratzinger, Teologia liturgii, s. 511.

25 Zob. A. Thomas, Górecki, Kraków 1998, s. 135.

26 Zob. H.M. Górecki, Miserere op.44, Kraków 1990, s. 31-34. 
jest podczas łamania Hostii i wyraża śpiew wobec umęczonego Chrystusa ${ }^{27}$. Pisał w tym kontekście Ratzinger:

(...) jeden z nich przebija prawy bok - serce - Jezusa, ,a natychmiast wypłynęła krew i woda" (J 19, 34). To godzina, o której zabijano baranki paschalne. W odniesieniu do nich przepis Prawa zabraniał łamania kości (Wj 12, 46). Jezus okazuje się tu prawdziwym Barankiem paschalnym, czystym i doskonałym ${ }^{28}$.

Co więcej, ostatnia część jest wyraźnie skontrastowana w stosunku do wcześniejszych. Prowadzenie głosów chóralnych poprzez łagodną linię melodyczną oraz konsonansowe współbrzmienia nadają fragmentowi cechy liturgiczne. Na szczególną uwagę zasługuje określenie ekspresyjne, które zamiast w języku włoskim, zostało napisane po polsku: btagalnie ${ }^{29}$. To zaakcentowanie ważności ostatniego fragmentu. Jak je określić? Pomoc stanowią dwie intuicje Mieczysława Tomaszewskiego. Po pierwsze, ów fragment, przez swoją radykalną inność i swoistą transcendentność, stanowi moment epifaniczny dzieła. To w teorii Tomaszewskiego miejsce przezierania w utworze muzycznym innej rzeczywistości - transcendentnej, sakralnej, boskiej ${ }^{30}$. Po drugie, nawiązując do omawianego dogmatu wcielenia, krakowski teoretyk sądził, że w przypadku Góreckiego słowa nie są dodane do tkanki muzycznej (i na odwrót). W przypadku twórczości Góreckiego, następująco sądził o symbiozie słowa i muzyki:

(...) dla jej określenia odwołam się do definicji, jaką stworzył Thrasybulos Georgiades w swojej wspaniałej monografii pieśni Schuberta. Schuberta jego zdaniem - wyróżnia to, że słowo bywa „wcielone w dźwięk”. Nie „pochłonięte przez dźwięk”, jak u Wagnera, ale właśnie w dźwięk „wcielone”. I to sformułowanie o charakterze sakralnym doskonale się do muzyki Góreckiego nadaje ${ }^{31}$.

A zatem utwór H.M. Góreckiego, orientuje się wokół zmiłowania pochodzącego od Boga, które może przynieść pokój również dziś. W teologii wcielenia oraz

Zob. B. Nadolski, Liturgika, 4: Eucharystia, Poznań 1992, s. 247.

28 J. Ratzinger, Jezus z Nazaretu, s. 538 (Opera Omnia, 6/1).

29 H.M. Górecki, Miserere op. 44, s. 2.

30 Zob. M. Tomaszewski, Muzyka w dialogu ze stowem, Kraków 2003, s. 12.

31 B. Bolesławska-Lewandowska, Górecki. Portret w pamięci, Kraków 2013, s. 122. 
wynikającej z niej teologii Baranka Bożego (nie łamania kości, ale przebicia serca), ma swe źródło przestrzeń miłosierdzia. Pisał kardynał:

(...) w Agnus Dei (Baranku Boży) spoglądamy ku Temu, który jest Pasterzem, a który dla nas stał się Barankiem i jako Baranek poniósł nasze winy. Słuszną jest zatem rzeczą również w tym momencie bić się w piersi i przypominać sobie samym, także zewnętrznie, że nasze winy przygniatały Jego ramiona ${ }^{32}$.

Wobec teologicznej linii interpretacji słowa Miserere, obecnej w Agnus Dei, dzieło stanowi muzyczny wgląd w Serce Chrystusa, które przynosi pokój i pojednanie. Gdyby bowiem Zbawiciel nie miał woli zbawienia świata, to nie udzielałby nam swojego zmiłowania, lecz gniew i karę. Zamiast sam umierać, wymierzyłby karę ludzkości. Tymczasem, jak wskazano w myśli Ratzingera, w Sercu Chrystusa dokonała się istota kultu religijnego i co za tym idzie istota kultury i estetyki - pojednanie. A zatem, zanoszona w utworze prośba, wynika z określonej wiedzy o Bogu. Ów system wiedzy to teologia. Górecki odwołując się do tekstów religijnych, nie negował ich znaczenia, ale przez kunsztowną tkankę muzyczną nadawał im głos we współczesności. Jednocześnie uzyskiwał dla swojego utworu przesłanie o niebagatelnej treści. Omawiany przykład muzyczny, znakomicie ukazuje powiązanie teologii i muzyki religijnej. Sakralne dzieło muzyczne stanowi artystyczny wyraz teologii, tzn. wynika z teologii i do niej prowadzi. Dzieje się tak dlatego, że nie sposób uczciwie zinterpretować Miserere op. 44, nie odwołując się do właściwego rozumienia cytowanych słów i ich konotacji teologicznych. Interpretując przesłanie, dociera się do warstwy religijnej - w tym przypadku zmiłowania pochodzącego od Zbawiciela. Czyż w dobie rozmaitych manifestów, a wówczas w dobie manifestu komunistycznego, teologiczne przesłanie utworu nie stanowiło jego szczególnej siły wyrazu? Jeżeli wnikniemy w ten poziom, okaże się, że dzieło kultury stanęło rzeczywiście naprzeciw antykultury, a sacrum naprzeciw profanum.

Aspekt miłosiernego Serca Pana Jezusa prowadzi do kolejnego dogmatu, na którym kard. Ratzinger opierał swoją chrystocentryczną interpretację estetyki:

(...) w męce Chrystusa podziwu godna estetyka grecka, z wymarzonym przez nią dotknięciem ciągle bezimiennego jednak Bóstwa, nie została przekreślona, lecz przekroczona. Doświadczenie piękna otrzymało nową

32 J. Ratzinger, Teologia liturgii, s. 163. 
głębię, nowy realizm. Ten, który jest samym pięknem, zgodził się być zbity, opluwany i cierniem ukoronowany ${ }^{33}$.

Dogmat odkupieńczej śmierci Zbawiciela jest jakby kolejną częścią symfonii, którą należy interpretować w odniesieniu do poprzednich (i na odwrót). Pojednanie, miłosierdzie i wola dobra, czyli miłość wcale nie oznacza trywialności. W pierwszej encyklice Deus caritas est, papież Benedykt XVI podał locus theologicus pojmowania miłości Boga:

(...) w Jego śmierci na krzyżu dokonuje się owo zwrócenie się Boga przeciwko samemu sobie, poprzez które On ofiarowuje siebie, aby podnieść człowieka i go zbawić - jest to miłość w swej najbardziej radykalnej formie. Spojrzenie skierowane na przebity bok Chrystusa (...) To tu może być kontemplowana ta prawda. Wychodząc od tego można definiować, czym jest miłośćc ${ }^{34}$.

Programowa encyklika tłumaczy współczesne rozumienie przebitego Serca Pana Jezusa, które w dobie przyjemności i konsumpcjonizmu oraz indywidualistycznego egoizmu, symbolizuje teologiczną istotę miłości. Papież nawiązał do 19. rozdziału Ewangelii według św. Jana, w którym znajduje się opis stwierdzenia zgonu dokonany przez rzymskiego żołnierza. $Z$ uwagi na powolną śmierć krzyżową, czasem dla przyspieszenia egzekucji przebijano bok włócznią lub łamano golenie - crurifragium $^{35}$. Choć we fragmencie nie pada literalnie słowo serce, to jednak biblistyka twierdzi, że wnętrze (gr. ko $\lambda i ́ \alpha)$, bok (gr. $\pi \lambda \varepsilon v \rho \alpha v)$ może oznaczać serce ${ }^{36}$. Ratzinger tłumacząc teologiczne powody tak drobiazgowego odnotowania przebicia boku, wskazał na potrzebę podkreślenia faktu prawdziwego ciała Pana Jezusa. Już wtedy pojawiły się błędy w rozumieniu Pana Jezusa:

(...) za istotne uważano jedynie słowo, naukę, orędzie, nie zaś „ciało”, żywe ciało Chrystusa, wykrwawione na krzyżu; że próbowano stworzyć chrześcijaństwo myśli i idei, z którego chciano usunąć rzeczywistość ciała - ofiarę i sakrament ${ }^{37}$.

\footnotetext{
33 J. Ratzinger, Jezus z Nazaretu, s. 715 (Opera Omnia, 6/2).

34 Benedykt XVI, Deus caritas est, Poznań 2005, nr 12.

35 Zob. K. Romaniuk, A. Jankowski, L. Stachowiak, Praktyczny komentarz do Nowego Testamentu, t. 1, Poznań-Kraków 1999, s. 576.

36 Zob., Zob. red., X. Leon-Dufour, Stownik teologii biblijnej, Poznań 1994, s. 873.

37 J. Ratzinger, Jezus z Nazaretu, s. 538 (Opera Omnia, 6/1).
} 
Stąd tak istotne jest symultaniczne rozumienie dogmatów. Chrystus rzeczywiście stał się człowiekiem, tzn. rzeczywiście miał ciało i serce. Rzeczywiście zmarł na krzyżu i faktycznie zmartwychwstał. W przywołanym fragmencie Ewangelii jest jeszcze jedno ważne słowo - przebicie. Dopiero „przebite serce Ukrzyżowanego stanowi dosłowne spełnienie proroctwa o sercu Boga, który swą sprawiedliwość obala przez współczucie i właśnie w ten sposób pozostaje sprawiedliwy" ${ }^{38}$. Przebicie Serca oznacza diametralnie inną logikę miłości i swoisty krystalicznie czysty przebłysk piękna. Choć wydawałoby się, że tutaj jest ono najbardziej niewidzialne i zakryte przez porażkę krzyża. Odpowiedzią na Dobrą Nowinę przyniesioną przez Chrystusa był krzyż, a nie aklamacja zbawczego majestatu. I przy tej okazji teolog podał miarę piękna, jakiej uczy przebite Serce: „taki koniec uczy nas, że sukces nie jest żadnym z imion Boga i że dążenie do sukcesu zewnętrznego i wymiernego nie jest chrześcijańskie. Drogi Boga są inne" ${ }^{39}$. Sztuka sakralna nie jest i nie może być nastawiona na sukces w rozumieniu współczesnego świata. Jej wartość nie leży w „lajkach” na portalach społecznościowych czy innego rodzaju popularności. Spojrzenie na Golgotę i liczba ludzi obecnych przy krzyżowej śmierci Pana Jezusa, w porównaniu do tłumów, które w tym czasie były w świątyni (przekonanych o oddawaniu czci Bogu przez składanie w ofierze baranka paschalnego) ukazuje socjologiczną porażkę. Tymczasem od strony teologicznej wydarzenie Golgoty stanowiło punkt zwrotny ludzkiej historii. Punkt wyjścia dla estetyki teologicznej kard. Ratzingera i inspirację (topos) dla nieprzebranej gromady kompozytorów, malarzy i rzeźbiarzy, którzy na przestrzeni wieków tworzyli na ten temat niekwestionowane arcydzieła sztuki. Odnośnie do samych symboli sztuki, pytał teolog w kontekście Serca Pana Jezusa:

(...) czy teraz - gdy rozdarła się zasłona świątyni i w przebitym sercu Ukrzyżowanego otworzyło się dla nas serce Boga - potrzebne są nam jeszcze święte miejsce i święty czas, pośredniczące symbole? Tak, potrzebujemy ich po to, żebyśmy przez „obraz” i znak uczyli się widzieć otwarte niebo, żebyśmy byli coraz bardziej zdolni poznawać tajemnicę Boga w przebitym sercu Ukrzyżowanego ${ }^{40}$.

Powyższy cytat ukazuje drogę do Boga poprzez sztukę sakralną. Jej artefakty pozwalają doświadczyć piękna, ogniskują uwagę na sacrum, które jest dostępne ludziom, dlatego że Bóg przyjął do siebie materię. A ponadto, przyjęcie materii

38 J. Ratzinger, Jezus z Nazaretu, s. 627 (Opera Omnia, 6/2).

39 J. Ratzinger, Teologia liturgii, s. 297.

40 J. Ratzinger, Teologia liturgii, s. 60-61. 
i stanie się człowiekiem oznaczało uniżenie się Boga, tak dalekie, że z miłości pozwolił na przerwanie swojego ziemskiego życia - tego, które jest empirycznie stwierdzalne (w historii był to fakt bicia serca i oddech ${ }^{41}$ ). Należy tu przytoczyć uwagę Ratzingera, że na Golgocie kapłanami nie byli oprawcy Pana Jezusa, ale On sam. Dokonana w sercu decyzja woli zbawienia człowieka stanowiła istotę kultu ${ }^{42}$, a co za tym idzie, istotę kultury i Ratzingera chrystocentryzm estetyki. Konkretnym symbolem Boskiej łaskawości wobec człowieka jest przebite Serce Jezusa. W nim odsłania się tajemnica Boga, który przyjmuje i akceptuje ludzi: „z Nim współ-działając i współ-ofiarując, stajemy się uczestnikami Tajemnicy. W ten sposób także nasze życie, nasze cierpienia, nadzieja i miłość mogą się stawać owocne w danym nam przez Niego nowym centrum”³. Jednak dokonuje się to dlatego, że Bóg we Wcieleniu wyszedł do człowieka i podzielił ludzki los. Stąd nieprzypadkowo kardynał użył dwukrotnie przedrostka „współ”. W encyklice Spe salvi Benedykt XVI powołał się na sentencję św. Bernarda z Clairvaux „impassibils est Deus, sed non inconpassibilis" (Bóg nie może cierpieć, ale może współcierpieć) ${ }^{44}$. To istotna kategoria dla rozumienia treści symbolu Serca Jezusa. Bóg stał się człowiekiem, ponieważ współczuje rodzajowi ludzkiemu i poszczególnej osobie ludzkiej. To współczucie sprawiło, że Bóg zgodził się na śmierć, aby uratować człowieka. Stąd też kardynał zauważył, że niewrażliwość wobec ludzkiego cierpienia była przez ojców Kościoła uważana za zachowanie pogan: „wiara chrześcijańska przeciwstawia temu Boga, który cierpi razem z ludźmi i w ten sposób pociąga nas do współcierpienia” ${ }^{45}$. Nie należy zapominać, że jedną z istotnych cech sztuki jest wywoływanie afektów, co tak szczególnie uwydatniło się w teorii muzyki okresu baroku. Uznano wtedy, że piękno ma poruszać i przekonywać ${ }^{46}$. Nie rozwijając w tym miejscu całej koncepcji Anny Brożek wyrażonej w książce Piękno i prawda, warto zauważyć, że autorka uwypukliła następujący fakt. Muzyka, przeciwnie do literatury (posługującej się metafora), odwołuje się do imitacji przeżyć poprzez określone właściwości dzieła muzycznego. Innymi słowy, niezależnie od języka czy kultury, pewien rodzaj muzyki będzie ewokował podobne odczucia. W analogii do oczywistości serca Maxa Schelera, Brożek mówiła o intuicji aksjologicznej, budującej na emocjach - a do tych odnosi się muzyka:

41 Por. R. Ferber, Podstawowe pojęcia filozoficzne, 2: Cztowiek. Świadomość. Ciato i dusza. Wolność woli. Śmierć, tłum. L. Kusak, A. Węgrzecki, Kraków 2008, s. 192.

42 Zob. J. Ratzinger, Teologia liturgii, s. 379.

43 J. Ratzinger, Teologia liturgii, s. 305.

44 Benedykt XVI, Spe salvi, Kraków 2007, nr 39.

45 J. Ratzinger, Jezus z Nazaretu, s. 90 (Opera Omnia, 6/1).

46 Zob. D. Szlagowska, Muzyka baroku, Gdańsk 1998, s. 24-25, 33. 
(...) na ogół nie odmawiamy percepcji prawa do wyposażania nas w trafne spostrzeżenia, tak nie możemy tylko z powodu takiej a nie innej genezy intuicji aksjologicznej twierdzić, że jej dane są z istoty pozbawione jakiejkolwiek wartości poznawczej (...) Nasze życie emocjonalne, jak muzyka, ma pewien rytm i tempo, ma odcienie, którym odpowiadają tonacje i akordy. To właśnie na podobieństwie wprost naszego życia emocjonalnego polega ów trudno uchwytny emocjonalny sens wielu utworów muzycznych ${ }^{47}$.

Wracając do myśli kard. Ratzingera, współodczuwanie, współcierpienie, którego symbolem jest Najświętsze Serce, odgrywa istotną rolę w estetyce muzycznej. Chrystocentryczna interpretacja pozwala uchwycić istotny sens estetyki muzyki sakralnej, polegający na pomocy człowiekowi we współdziałaniu z Bogiem, czyli realizacji kultu. Ratzinger wskazał na postać Mater Dolorosa, której przebite mieczem boleści serce: „jest prawzorem tej najgłębszej postawy wiary chrześcijańskiej” ${ }^{48}$.

Mater Dolorosa pojawia się w twórczości Henryka Mikołaja Góreckiego m.in. w pierwszej części III Symfonii „Symfonia pieśni żatosnych” op. 36. W centralnym miejscu znajduje się fragment Lamentu świętokrzyskiego, który stanowi literacką interpretację odkupieńczej śmierci Zbawiciela. Kompozytor wybrał tekst zawierający monolog liryczny Matki Najświętszej. Każda strofa została opatrzona określeniami ekspresyjnymi, podyktowanymi teologicznym znaczeniem słów, np. żal na odejście Syna posiada dyspozycję - doloros $0^{49}$. Jednakże część posiada ważny wątek chrystologiczny. Otóż lament znajduje się pomiędzy polifoniczną fakturą kanonu. Temat został skompilowany z dwóch pieśni koncentrujących się na Chrystusie: Oto Jezus umiera ze Śpiewnika kościelnego ks. Jana Siedleckiego oraz Niechaj bendzie pochwalony ze zbiorów ks. Władysława Skierkowskiego ${ }^{50}$. A zatem muzyka zaczerpnięta z kultu religijnego opiewa Jezusa Chrystusa, każąc patrzeć i chwalić umierającego. Co ciekawe, kanon rozpoczyna się od kolejno włączających się dziesięciu grup instrumentów smyczkowych. W ten sposób tworzy się dziesięciokrotne zawołanie podyktowane źródłowymi cytatami - jakby dziesiątek różańca tajemnicy bolesnej. Mówił kompozytor: „Wpadłem na pomysł, by nie używać krótkiego tematu, ale naprawdę długiego, nawet dłuższego niż najdłuższy temat fugi. Temat ten miał służyć jako podstawa początkowego kanonu. Dlatego postanowiłem użyć pieśni religijnej" ${ }^{51}$.

\footnotetext{
47 A. Brożek, Piękno i prawda, Kraków 2017, s. 51, 46.

48 J. Ratzinger, Jezus z Nazaretu, s. 90 (Opera Omnia, 6/1).

49 H.M. Górecki, III Symfonia „Symfonia pieśni żatosnych” op. 36, Kraków 1985, s. 19.

50 A. Thomas, Górecki, s. 115-116.

51 M. Trochimowczyk, Composing is a Terribly Personal Matter, https://polishmusic.usc.edu/ research/public-ations/ polish-music-journal/vol6no2/conversation-with-gorecki (31.03.2020).
} 
Przykuwa jednak szczególną uwagę zakończenie lamentu i drugie wejście kanonu. Otóż na zaledwie dwóch taktach pojawia się silny kontrast dynamiczny ( $p$-quasiff). W drugim z taktów (t. 369) kończy się tekst Maryi sugerujący śmierć Pana Jezusa („bo już idziesz ode mnie, moja nadzieja miła”2 ) i jakby odpowiedź stanowi pełne brzmienie kanonu - wraz ze wspomnianymi cytatami melodycznymi. To poruszenie jest typowe dla planktu ${ }^{53}$ i wynika z racji teologicznych. Maryja mówi do Chrystusa, a muzyka kanonu niejako odpowiada z pełną siłą wyrazu: „Oto Jezus umiera”. Kunszt muzyki Góreckiego pozwala współodczuwać wydarzenie Golgoty. Poświadczona przebiciem boku śmierć Chrystusa stanowiła dla Maryi ogromny dramat. Ten afekt cierpiącego serca Maryi i uwydatnienie momentu zgonu Jezusa Chrystusa na krzyżu, znajduje swój wyraz w kontraście dynamicznym obecnym w muzyce. Ów fragment dzieła muzycznego, poprzez swoją silną emocję, połączoną z określonym tekstem słownym, stanowi środek do współodczuwania dramatu Golgoty. Schelerowskie adequatio cordis, w tym wypadku słuchacza, wymaga właściwej odpowiedzi serca zarówno wobec muzyki, jak i wydarzenia oraz Osób w niej wskazanych. Przykład z pierwszej części III Symfonii ukazuje, jak istotny wymiar sztuki muzycznej (budowanie emocji i współodczuwania) wiąże się i znajduje swoje uzasadnienie kulturowe w teologii katolickiej. A konkretnie w chrystologicznej prawdzie dotyczącej Najświętszego Serca Pana Jezusa. Przebite Serce to znak wspólnoty Boga z człowiekiem także w bólu, cierpieniu i śmierci. Pisał Ratzinger:
(...) kto wierzy w Boga - w Boga, który w oszpeconej postaci Ukrzyżo- wanego objawił się jako miłość „do końca” (J 13, 1), ten wie, że piękno jest prawdą, a prawda jest pięknem, ale patrząc na cierpiącego Chrystusa, uczy się także, że piękno prawdy zawiera w sobie zranienie, ból, a nawet mroczną tajemnicę śmierci, i można je znaleźć tylko w przyjęciu bólu, a nie w przechodzeniu obok niego ${ }^{54}$.

Powyższy cytat ukazał intuicję kardynała, który opowiada się za rozumieniem piękna w kontekście prawdy. Natomiast spojrzenie na miłość do końca - przebicie Najświętszego Serca, ukazuje, że bez Chrystusa umęczonego nie można poznać piękna prawdy. Innymi słowy, ucieczka bądź bunt sztuki wobec cierpienia będzie jedynie fałszem i brzydotą - antyestetyką. Pisał Henryk Kiereś, rozważając związki sztuki z prawdą:

\footnotetext{
52 H.M. Górecki, III Symfonia „Symfonia pieśni żatosnych” op. 36, s. 21.

53 Zob. T. Michałowska, Średniowiecze, Warszawa 1995, s. 448.

54 J. Ratzinger, Jezus z Nazaretu, s. 711 (Opera Omnia, 6/2).
} 
(...) dzieło sztuki jest zatem prawdziwe w pełnym sensie „prawdy” (simpliciter - absolutnie), kiedy i wiedza o świecie i o sztuce oraz kiedy forma-koncepcja dzieła pozostają w zgodzie z sobą i realnym światem. Takie dzieło realnie bogaci świat, jest ono faktem kulturotwórczym, czyli wpisuje się w ostateczny cel życia człowieka. Natomiast dzieło sprawne artystycznie, ale wyrastające z fałszu poznawczego dziedziczy fałsz! Jest ono faktem kulturowym, tak, jak są nimi dzieła antysztuki - lecz nie jest faktem kulturotwórczym! ${ }^{55}$

Cierpienie, ból i śmierć to trudne doświadczenia człowieka. Prawda o Sercu Jezusa ukazuje, że należy je przyjąć, tak jak przyjął je sam Bóg. To ma napawać nadzieją i w tym leży jej autentyczne piękno. Samo umęczenie nie jest pocieszające, natomiast rys chrystologiczny, czyli przyjęcie cierpienia przez Jezusa i pokonanie przez zmartwychwstanie już tak.

Dla kard. Ratzingera autentyczny kult oznacza człowieka odpowiadającego w wolności na miłość Boga ${ }^{56}$ (redditus): „chodzi tu nie o drogę lotu w przestrzeń kosmiczną, lecz drogę "lotu w przestrzeni» serca: od wymiaru zamykania się w sobie do nowego wymiaru Boskiej miłości ogarniającej cały świat" ${ }^{57}$. Wejście na drogę miłości, czyli wyjście z postawy egoizmu, oznacza zgodę na otwarcie serca. Tymczasem miłość bez cierpienia to fikcja i zasadnicza treść antykulturowej propagandy. Sztuka sakralna ma zadanie wytyczania estetycznej drogi pośród bezdroży i absurdów antyestetyki, na które nie ma miejsca w kulcie Kościoła katolickiego:

(...) to jest najwznioślejsza, służebna funkcja muzyki, w której pełnieniu nie musi wyrzekać się ona wielkości artystycznej - przeciwnie nawet, dopiero w ten sposób osiąga ją całkowicie: oczyszcza zasypaną pyłem drogę do serca, do jego najgłębszego wnętrza, gdzie spotyka się bezpośrednio ze Stwórcą i Odkupicielem. Wszędzie, gdzie to następuje, muzyka staje się droga, która prowadzi do Jezusa - drogą, na której Bóg ukazuje nam swoje zbawienie ${ }^{58}$.

Reasumując, chrystocentryczna estetyka kard. Ratzingera opiera się na trzech dogmatach. Stworzenie wskazuje na istotę kultu chrześcijańskiego, który cechuje

55 H. Kiereś, Filozofia sztuki, Lublin 2020, s. 226-227.

56 Zob. J. Ratzinger, Jezus z Nazaretu, s. 546 (Opera Omnia, 6/1).

57 J. Ratzinger, Jezus z Nazaretu, s. 578 (Opera Omnia, 6/1).

58 J. Ratzinger, Teologia liturgii, s. 567. 
się ideą powrotu stworzenia do Stwórcy. Ów akt dokonał się w Sercu Chrystusa, który pojednał ludzkość z Bogiem. Kult chrześcijański znajduje swoje ucieleśnienie w liturgii Kościoła. Szczególnym przykładem kultu skierowanego do Serca Pana Jezusa jest litania, której melodię zacytował Górecki do własnych słów modlitwy do św. Wojciecha umieszczonej w utworze Salve sidus Polonorum. Z kolei dogmat Wcielenia wskazuje na Zbawiciela, który stał się człowiekiem. A co za tym idzie, przyjął ludzkie ciało i serce, którego symbol oznacza duchowe wnętrze człowieka. Serce Chrystusa ukazuje życzliwość Boga wobec ludzkości oraz wolę pojednania. Zdaje się, że do tych treści odwoływał się Górecki, komponując swoje Miserere op. 44. Utwór napisany w reakcji na fizyczne represje komunistycznej władzy wobec polskiego narodu. Dogmat Odkupienia wskazuje w teologii Josepha Ratzingera na aspekt współcierpienia Boga z ludźmi. Chrystus dając przebić swoje Serce, ukazuje istotę kultu i kultury, pełne poświęcenie się z miłości. Spojrzenie na przebite Serce Pana Jezusa jest dla kardynała istotą estetyki teologicznej. Scenę zbawczej śmierci ukazuje pierwsza część III Symfonii Góreckiego. Za pomocą języka muzycznego kompozytor umożliwił słuchaczom współodczuwać dramat Maryi, opłakującej zgon umiłowanego Syna. Muzyka stanowi artystyczny rezonans teologii śmierci krzyżowej, której punktem kulminacyjnym jest poświadczenie zgonu - przebicie Serca. A zatem wychodzenie z własnego ja (prawdziwy kult - osobowość), dbałość o dobro i pojednanie (wcielenie) oraz współodczuwanie (odkupienie - współcierpienie) jako owoc prawdziwej miłości, to teologiczne podwaliny dla piękna. Zarysowane kategorie pozwalają nie tylko na właściwe uprawianie kultury, ale także na konstruktywny sprzeciw wobec roszczeń antykultury. W dobie rozmaitych rewolucji i rewolucjonistów wskazywanie na Serce Pana Jezusa podkreśla podstawowy fakt kulturotwórczy: „chrześcijaństwo nie zaczyna się od rewolucjonisty, lecz od męczennika" 59 .

59 J. Ratzinger, Wprowadzenie do chrześcijaństwa, s. 621. 


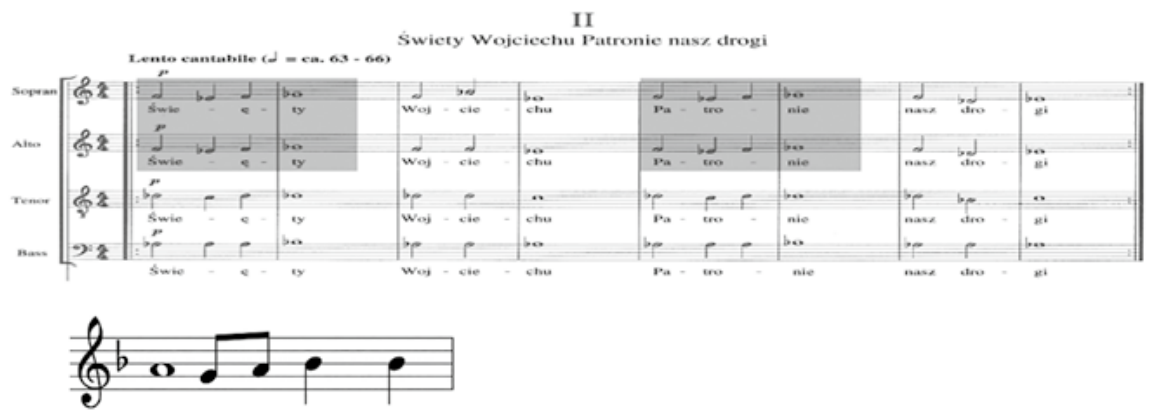

1. Przyktad nutowy: H.M. Górecki, Salve sidus Polonorum op. 72, cz. 2, t. 1-8 oraz fragment melodii wileńskiej Litanii do Najświętszego Serca Pana Jezusa. Ilustracja przedstawia sposób zacytowania przez kompozytora melodii litanijnej w Kantacie o św. Wojciechu.

\section{Abstrakt \\ Serce Jezusa jako istota chrystocentrycznej estetyki Josepha kard. Ratzingera/Benedykta XVI. Studium teologiczno-muzyczne na przykładzie twórczości Henryka Mikotaja Góreckiego}

Joseph kard. Ratzinger w swojej twórczości teologicznej poświęcał uwagę estetyce, a zwłaszcza estetykom muzyki sakralnej. Interpretację opierał na teologii dogmatycznej nakierowanej chrystologicznie. Samą zaś estetykę wiązał z faktem przebicia Serca Pana Jezusa na krzyżu. Twierdził bowiem, że prawdziwe piękno łączy się z prawdą i nie może zaistnieć bez przyjęcia cierpienia, czego wyrazem jest przebicie serca. W przeciwnym razie piękno byłoby fałszywe, ponieważ odwodziłoby od ludzkiego życia. Tymczasem Chrystus stał się człowiekiem, gdyż współczuł ludziom. Również ta kategoria ma ważne miejsce w estetyce muzyki sakralnej. Droga piękna to droga powrotu do Boga w prawdzie. Henryk Mikołaj Górecki to kompozytor, którego twórczość często jest nadmiernie wiązana z postacią Maryi. Tymczasem Jezus Chrystus również ma swoje miejsce w muzycznym dorobku Góreckiego, również w aspekcie Najświętszego Serca.

Stowa kluczowe: Jezus Chrystus, Serce Jezusa, Ratzinger, Górecki, teologia, muzyka, teologia muzyki, estetyka 


\begin{abstract}
The Heart of Jesus as the Essence of Christocentric Aesthetics Joseph card. Ratzinger / Benedict XVI. A Theological and Musical Study Based on the Works of Henryk Mikotaj Górecki
\end{abstract}

Joseph card. Ratzinger in his theological works, devoted an important place to the aesthetics, especially the aesthetics of sacred music. He based his interpretation on the dogmatic theology directed towards Christology. He associated aesthetics with the fact that the Heart of Jesus Christ was pierced on the cross. He argued that true beauty is linked to truth and cannot exist without suffering, which is expressed by piercing the heart. Otherwise, beauty would be false as it would distract from human life. Meanwhile, Christ became a man because he felt compassion for people. This category also plays an important role in the aesthetics of sacred music. The way of beauty is the way to return to God in truth. Henryk Mikołaj Górecki is a composer whose work is often excessively associated with the figure of Mary. Meanwhile, Jesus Christ also has his place in Górecki's musical output, also in the aspect of the Sacred Heart.

Keywords: Jesus Christ, the Heart of Jesus, Ratzinger, Górecki, theology, music, theology of music, aesthetics

\title{
Bibliografia
}

Benedykt XVI, Deus caritas est, Poznań 2005.

Benedykt XVI, Spe salvi, Kraków 2007.

Bolesławska-Lewandowska B., Górecki. Portret w pamięci, Kraków 2013.

Brożek A., Piękno i prawda, Kraków 2017.

Ferber R., Podstawowe pojęcia filozoficzne, 2: Cztowiek. Świadomość. Ciato i dusza. Wolność woli. Śmierć, tłum. L. Kusak, A. Węgrzecki, Kraków 2008.

Górecki H.M., III Symfonia „Symfonia pieśni żatosnych” op. 36, Kraków 1985.

Górecki H.M., Miserere op.44, Kraków 1990.

Górecki H.M., Salve, sidus Polonorum: St. Adalbert cantata op. 72 (1997-2000), London 2001.

Kiereś H., Filozofia sztuki, Lublin 2020.

Michałowska T., Średniowiecze, Warszawa 1995.

Nadolski B., Liturgika. IV Eucharystia, Poznań 1992.

Paczkowska-Łagowska E., O historyczności cztowieka, Gdańsk 2012.

Pikulik J., Święty Wojciech w polskiej muzyce średniowiecznej, Warszawa 1996.

Potocka A.M., Nowa estetyka, Warszawa 2016. 
Ratzinger J., Jezus z Nazaretu, tłum. M. Górecka, W. Szymona OP, Lublin 2015 (Opera Omnia, 6/1).

Ratzinger J., Jezus z Nazaretu, tłum. W. Szymona OP, Lublin 2015 (Opera Omnia, 6/2). Ratzinger J., Teologia liturgii, tłum. W. Szymona OP, Lublin 2012 (Opera Omnia, 11). Ratzinger J., Wprowadzenie do chrześcijaństwa, tłum. R. Biel, M. Górecka, Lublin 2017 (Opera Omnia, 4).

Ratzinger J., Zmartwychwstanie i życie wieczne, tłum. J. Kobienia, Lublin 2014 (Opera Omnia, 10).

Stownik tacińsko-polski, red. K. Kumaniecki, Warszawa 1982.

Stownik teologii biblijnej, red. X. Leon-Dufour, Poznań 1994.

research/public-ations/ polish-musicjournal/vol6no2/conversation-with-gorecki (31.03.2020).

Romaniuk K., Jankowski A., Stachowiak L., Praktyczny komentarz do Nowego Testamentu, t. 1, Poznań-Kraków 1999.

Siedlecki J., Śpiewnik kościelny, Kraków 2007.

Siedlik W., Henryk Mikotaj Górecki i jego muzyka, „Pro Musica Sacra” 10 (2012), s. 89-103. Szlagowska D., Muzyka baroku, Gdańsk 1998.

Szymański S., Litania do Najświętszego Serca Jezusowego, „Ateneum Kapłańskie” 62 (1961) z. 3, s. 269-271.

Thomas A., Górecki, Kraków 1998.

Tomaszewski M., Muzyka w dialogu ze stowem, Kraków 2003.

Trochimowczyk M., Composing is a Terribly Personal Matter, https://polishmusic.usc.edu/ research/public-ations/ polish-music-journal/vol6no2/conversation -with-gorecki (16.06.2021). 